\title{
Structure and management of traditional agroforestry vineyards in the high valleys of southern Bolivia
}

\author{
Pablo Oliva Oller • Martin Notaro $\cdot$ Erick Langer • \\ Christian Gary ${ }^{(1)}$
}

Received: 14 June 2021 / Accepted: 20 December 2021 / Published online: 5 February 2022

(C) The Author(s) 2022

\begin{abstract}
In the south of Bolivia, a group of traditional wine growers are distinguished by the cultivation of grapevines on native trees that serve as tutors. These growers currently represent one of the few examples of agroforestry vineyards in the world. They offer an opportunity to analyze the structure and management of these cropping systems, and to identify the ecosystem services provided by the combination of grapevines that are trained on trees. We characterize 29 agroforestry vineyards located in three high valleys in southern Bolivia, describing the main farm features, the structure and management of the vineyards, and the advantages of on-tree vine staking as recorded by the farmers. Farms were small ( 2.2 ha
\end{abstract}

P. Oliva Oller $(\bowtie)$

IDEPRO Desarrollo Empresarial, Ingavi N ${ }^{\circ} 339$, Tarija,

Bolivia

e-mail: pablorodrigooliva@gmail.com

P. Oliva Oller

Fundación FAUTAPO, Cochabamba Nº ${ }^{\circ}$, Camargo,

Bolivia

M. Notaro

CIRAD, UMR ABSys, 34398 Montpellier, France

M. Notaro · C. Gary

ABSys, Univ Montpellier, CIHEAM-IAMM, CIRAD,

INRAE, Institut Agro, Montpellier, France

E. Langer

School of Foreign Service, Georgetown University,

Washington. D.C., USA on average), with about half viticulture and half other crops and forage. The workforce was about half family and half employees. The most commonly used tree species were the molle tree (Schinus molle) and chañar tree (Geoffroea decorticans), and the majority of grape varieties grown were landraces such as "Negra criolla" and "Vicchoqueña." The main cultivation techniques were pruning of the trees and vines, application of manure more than mineral fertilizers, gravity irrigation, and application of few pesticides. The main services farmers expected from trees were protection against climate hazards and flooding, disease control, maintenance of soil fertility, and higher yields. Agroforestry is a promising option for the agroecological transition of viticulture, which deserves further studies at both plot and farm scales.

Keywords Traditional wine growing systems . Agroforestry · Viticulture · On-tree vine staking · Ecosystem services

\section{Introduction}

Like other agricultural sectors, viticulture has evolved during the second half of the twentieth century towards monocrop systems that are highly dependent on inputs, particularly on plant protection products. This has resulted in better control of grape production, but also created environmental impacts that are detrimental to the sustainable development of wine 
growing areas: water and air pollution, soil degradation, and biodiversity loss (Altieri and Nicholls 2002). To remedy this, viticulture must produce not only grapes but also ecosystem services, with some expected by the society (e.g., environmental quality, human health, landscapes) and others useful to viticulture itself (e.g., regulation of pests, maintenance of soil fertility) (Garcia et al. 2018). The sustainable restoration of a good balance between agricultural production and provision of ecosystem services requires the reintroduction of biodiversity at the scales of fields and landscapes (Duru et al. 2015).

Yet vineyards have not always been monocrop systems. In ancient Rome, grapevines were trained on trees and associated with arable crops and livestock (van Limbergen 2020). As a matter of fact, species of the genus Vitis are usually liana that naturally grow on trees (Keller 2020). Such agroforestry systems have been cultivated for centuries, but very few of them remain at the present time. Some remain in Italy (Paris et al. 2019), France (Dupraz and Liagre 2019), Portugal (Altieri and Nicholls 2002), and Bolivia (Oliva et al. 2019). In the few modern vineyards that have been reported, rows of vines are alternated with rows of trees to make these agroforestry systems compatible with mechanization (Gosme et al. 2019; Bourgade et al. 2020). These agroforestry vineyards exhibit a high level of biodiversity, which is associated with environmental sustainability and therefore considered favorable to the agroecological transition of farming systems (Maraux et al. 2013).

The ecosystem services that trees can provide in vineyards have seldom been assessed. Altieri and Nicholls (2002) counted more species of predators and parasites of two grape pests in agroforestry than in monocrop vineyards. Barbar et al. (2006) also reported that trees planted in vineyards improved the biological control of pest mites. Lang et al. (2019) observed better soil nitrogen and water availability when grapevines were trained on trees. More generally, the combination of forest trees and crops in agroforestry systems may bring several ecosystem services: soil and water conservation, nutrient cycling, carbon sequestration, regulation of pests and diseases, mitigation of climate extremes, and biodiversity conservation. These were identified in both temperate and tropical conditions (Malézieux et al. 2009). Yet the provision of these ecosystem services varies a lot depending on the structure of the agroforestry system and on local conditions of weather, soil, and management.

The present study is aimed at describing the management and farmers' expectations of traditional agroforestry vineyards in the high valleys of southern Bolivia. In this region, traditional winegrowers are distinguished by the cultivation of centuries-old vineyards with creole varieties of grapevines staked on native trees (Oliva et al. 2019). They produce table grapes, wine, and "singani" brandy, mainly sold on the domestic market (Buitrago Soliz 2014). A survey was carried out on 29 farms in three valleys to characterize the farms, the structure and management of agroforestry cropping systems, and the ecosystem services expected by farmers from trees in vineyards. The results shed light on the potential for restoring the sustainability of wine growing systems through agroforestry.

\section{Materials and methods}

\section{Study site}

The study was located in three high valleys of southern Bolivia (Fig. 1). The Cinti Valley $\left(20^{\circ} 37^{\prime} \mathrm{S}, 65^{\circ}\right.$ $\left.12^{\prime} \mathrm{W}\right)$, located in the Department of Chuquisaca at an altitude of 2850 m.a.s.l., is the second largest wine growing area in the country with 215 ha of cultivated area (FAUTAPO 2010), with an average annual rainfall of $300 \mathrm{~mm}$ concentrated from November to March and an average annual temperature of $18{ }^{\circ} \mathrm{C}$. The number of chilling hours $\left(<7^{\circ} \mathrm{C}\right)$ is 295 per year on average (Molina Antelo et al. 2011). The soils have a clay loam texture, with an average $\mathrm{pH}$ of 7.3 and an organic matter (OM) content of $2.1 \%$ (Molina Antelo et al. 2011). The Cotagaita Valley $\left(20^{\circ} 42^{\prime} \mathrm{S}, 65^{\circ} 39^{\prime}\right.$ $\mathrm{W})$, located in the Department of Potosí and adjacent to the Cinti Valley at an altitude of 2605 m.a.s.1., has 10 ha of vineyards (FAUTAPO 2010). The average annual rainfall is $250 \mathrm{~mm}$ and the average annual temperature is $19{ }^{\circ} \mathrm{C}$. The soils have fine to very fine sandy clay loam to silt loam and clay loam textures, with $\mathrm{pH}$ 7.7-8.1 and an average OM content of $2.2 \%$ (Chuya 2011). The Paicho Valley $\left(21^{\circ} 08^{\prime} \mathrm{S}\right.$, $64^{\circ} 57^{\prime} \mathrm{W}$ ) belongs to the department of Tarija at an altitude of 2547 m.a.s.l., and has 25 ha of vineyards (FAUTAPO 2010). The average annual rainfall is $250 \mathrm{~mm}$ and the average annual temperature is $17{ }^{\circ} \mathrm{C}$ 


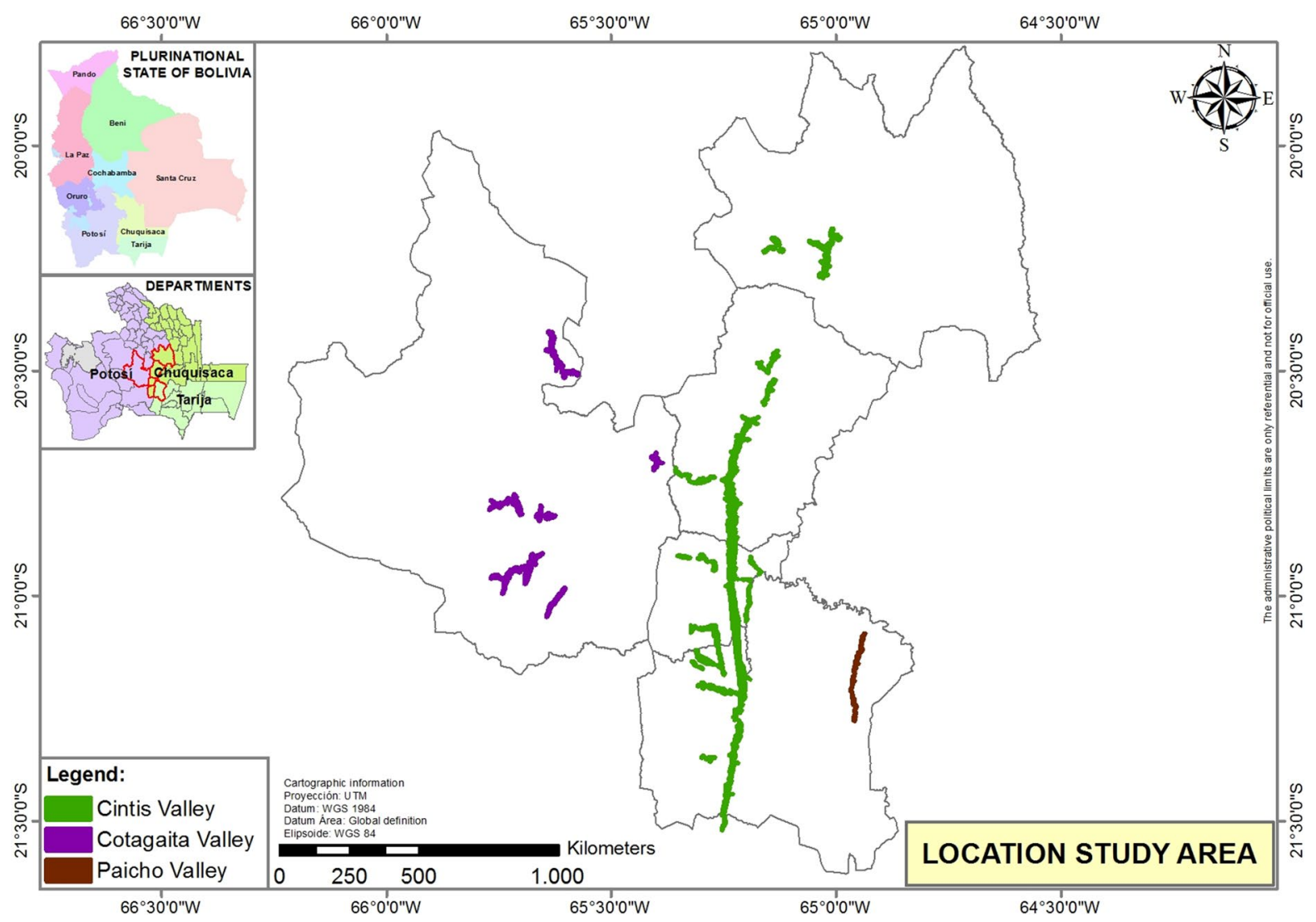

Fig. 1 Location of the three high valleys of southern Bolivia with traditional vineyards

(SENAMHI 2020). The soil texture is loam with a predominance of sandy loam. The average soil $\mathrm{pH}$ is 7.0 and the average OM content $1.5 \%$ (Municipio Méndez 2009).

One of the main characteristics of these three valleys is that only small plots can be cultivated due to the topography of the region. Crops are located on the banks of the rivers and the main environmental risk for the vineyards is floods.

\section{Survey among winegrowers}

Twenty-nine surveys were carried out with traditional grape growers in the three valleys ( 13 from Cinti, 6 from Cotagaita, and 10 from Paicho) during the second half of 2018 and the first half of 2020. The farmers were located through support institutions, community leaders, and agricultural technicians in the region. There are an estimated 80 traditional grape producers located in the study area, of which about
$40 \%$ were surveyed. The survey form included a set of technical and socioeconomic variables, selected for their ability to describe the structure and functioning of the cropping systems (Conway 1987; Escobar and Berdegué 1990; Oliva 2021): farm features (farm area, vineyard and other crop areas, permanent/nonpermanent and family/hired workforce), agroeconomic performance (grape yield and inputs), cropping management (tree species, grape cultivars, vine and tree pruning, irrigation, manure supply and mineral fertilization, weeding, tillage, crop protection), and services expected from trees. Costs related to wine production were calculated by adding labor and input costs (energy, fertilizers, and pesticides). The gross margin was calculated as the difference between the turnover from the sale of wine and production costs. The identification of the ecosystem services expected by the grape growers was declarative (Cerdán et al. 2012). The survey questionnaire was open-ended; no list was proposed so as not to bias the 
growers' response, and the growers named the advantages that the trees provided to vine cultivation without ranking them. The frequency analysis was conducted on the basis of the first three services cited by each winegrower.

Additionally, tree and grapevine densities were measured in a subsample of 13 vineyards located in the three valleys. In each vineyard measuring more than this area, a $1000 \mathrm{~m}^{2}$ sample plot $(31.6 \times 31.6 \mathrm{~m})$ was delimited with ropes, stakes, and squares. The plot was located in an area considered to be representative of the vineyard in terms of tree density and species, preferably in the center to avoid edge effects. On each $1000 \mathrm{~m}^{2}$ plot, we inventoried and counted the number of all associated trees per species, and the number of vines staked on trees or not. Vineyards of less than $1000 \mathrm{~m}^{2}$ were described entirely.

\section{Data analyses}

Descriptive statistics and measures of dispersion were used to describe the agroforestry systems. We analyzed the variability of the management variables and the relationships between them. Multidimensional analyses (PCA) and a typology of vineyard management (HCA) were carried out in R (R Core Team 2020) with the FactoMineR package (Lê et al. 2008). This analysis enabled us to test if technical management impacted agroeconomic performance (disease and pest pressure, yield, costs, and income). Moreover, we examined if management correlated with farmers' expectations regarding the usefulness of the vineyard-tree association.

\section{Results}

Socioeconomic characteristics of farms and vineyards

The 29 surveyed grape growers had farms of $0.25-8$ ha (Table 1). Forty-four percent of farms were between 0.25 and 1 ha, $37 \%$ of farms were between 2 and 3.5 ha, and only $19 \%$ were larger than 4 ha. The vineyard size ranged from 0.1 to $7 \mathrm{ha}$; $85 \%$ of the growers had a vineyard of less than 1 ha. The other crops they grew were, in order of frequency, vegetables (potato, maize, broad bean, onion, tomato, carrot), fruit (peach, plum, apple), and fodder crops (alfalfa) (data not shown). In some cases, these other crops were grown in the vineyards.

The producers generally had a long experience in the cultivation of grapevines and trees, with an average of 35 years (not shown), as viticulture was a family tradition. Work in the vineyards was partly carried out by family labor, both permanent and casual. Non-family labor from the surrounding area was also employed, mostly temporary. Permanent nonfamily labor was common in the largest vineyards. Most of the producers transformed their production into wine and "singani" brandy, and more than half of them marketed their production individually in their production area or in the surrounding regions.

Table 1 Socioeconomic characteristics of 29 farms with traditional grape growing systems in southern Bolivia

\begin{tabular}{|c|c|c|c|}
\hline Variable & Minimum & Maximum & Mean (SD) \\
\hline Farm area (ha) & 0.25 & 8 & $2.2(1.9)$ \\
\hline Vineyard area (ha) & 0.10 & 7 & $1.0(1.8)$ \\
\hline Other crop area* (ha) & 0.10 & 7 & $1.1(1.5)$ \\
\hline Permanent family workforce (FTE) & 0 & 3 & $1.6(0.8)$ \\
\hline Nonpermanent family workforce (FTE) & 0 & 5 & $1.4(1.5)$ \\
\hline Permanent nonfamily workforce (FTE) & 0 & 3 & $0.8(1.0)$ \\
\hline Nonpermanent nonfamily workforce (FTE) & 0 & 10 & $3.4(2.1)$ \\
\hline Grape yield $\left(\mathrm{hL} \mathrm{ha}^{-1}\right)$ & 10 & 159 & $47(35)$ \\
\hline Turnover from viticulture (USD ha ${ }^{-1}$ ) & 460 & 9065 & $2643(1907)$ \\
\hline Grape production cost (USD ha-1) & 72 & 2406 & $905(601)$ \\
\hline Gross margin (USD ha ${ }^{-1}$ ) & 180 & 7303 & $1738(1590)$ \\
\hline
\end{tabular}

*Grapevines and other crops may coexist in the same fields 
Grape yield was highly variable, around an average of $47 \mathrm{hL} \mathrm{ha}^{-1}$, and so was the economic performance. The average turnover was $2643 \mathrm{USD} \mathrm{ha}^{-1}$ and the average production cost was $905 \mathrm{USD} \mathrm{ha}^{-1}$, which represents $34 \%$ of the average turnover. The main production costs were casual nonfamily labor (70\%), crop protection treatments (25\%), and fuel (5\%).

Structure of the associations between grapevines and trees

There were 1-3 tree species per plot. "Molles" (Schinus molle) were found in all plots (Table 2). Secondary species were "chañares" (Geoffroea decorticans) and, in smaller numbers, "tacos" (Prosopis alba), "algarrobos" (Ceratonia siliqua), "churquis" (Acacia caven), peach trees (Prunus persica), and "nogales" (Juglans australis). In 37\% of the vineyards, the molle tree was the only tree species; in $47 \%$ of the vineyards it was associated with another tree species; and in $16 \%$ of the vineyards it was associated with two other tree species.

We asked grape growers to name only the three main grape varieties in their plot, yet other minor varieties could be present. Among the cited varieties, "Negra Criolla" appeared in most of the plots, "Moscatel de Alejandría" and "Vicchoqueña" in about half of the plots, whereas "Pedro Ximenez" and "Cabernet" appeared only once (Table 2). All were ungrafted plants obtained from cuttings.

The grapevine density observed on a subsample of 13 vineyards ranged from 3050 to 9500 vines $\mathrm{ha}^{-1}$ in the Cinti Valley, from 5100 to 7200 vines $\mathrm{ha}^{-1}$ in the Cotagaita Valley, and from 1550 to 6650 vines $\mathrm{ha}^{-1}$ in the Paicho Valley. The tree density ranged from

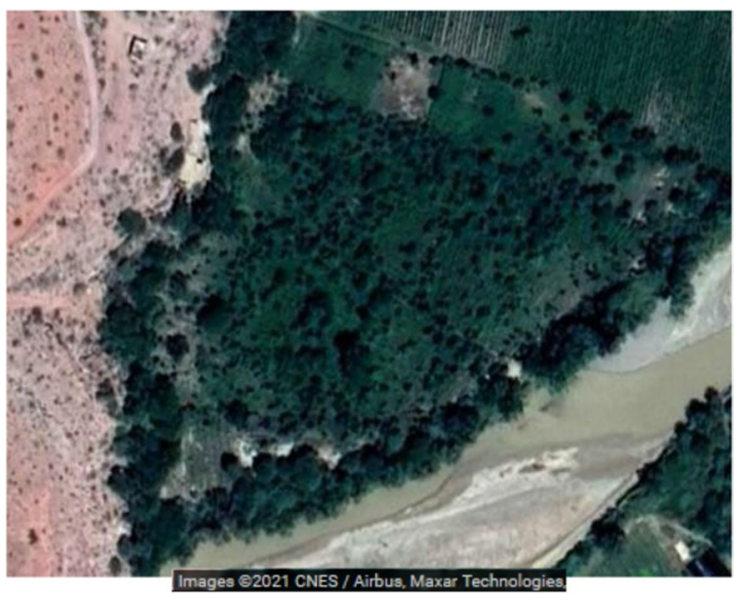

Fig. 2 An example of a vineyard with grapes grown on trees in the Cinti Valley (Google Maps, accessed 15 January 2021)

240 to 440 trees $\mathrm{ha}^{-1}$ in the Cinti Valley, from 330 to 950 trees $\mathrm{ha}^{-1}$ in the Cotagaita Valley, and from 640 to 1020 trees ha ${ }^{-1}$ in the Paicho Valley. The spatial distribution of trees was sometimes aligned but often irregular, providing the crop with a wooded environment (Figs. 2, 3). On average, 18\% of vines were staked on trees with 2.3 vines per tree in the Cinti Valley, $30 \%$ of vines were staked on trees with 4.9 vines per tree in the Cotagaita Valley, and $28 \%$ of vines were staked on trees with 1.2 vines per tree in the Paicho Valley. According to the grape growers, they established vine stocks on trees 5-6 years after their development.

Table 2 Number of citations of tree species, grape cultivars (local names), and farming practices over 29 agroforestry vineyards in southern Bolivia

\begin{tabular}{|c|c|c|c|c|c|}
\hline Tree species & Citations & Grape cultivars & Citations & Farming practices & Citations \\
\hline Molle (Schinus molle) & 29 & Negra criolla & 26 & Irrigation & 29 \\
\hline Chañar (Geoffroea decorticans) & 10 & Moscatel de Alejandria & 17 & Vine pruning & 29 \\
\hline Taco (Prosopis alba) & 6 & Vicchoqueña & 12 & Green pruning & 29 \\
\hline Algarrobo (Ceratonia siliqua) & 4 & Pedro Ximenez & 1 & Tree pruning & 29 \\
\hline Churqui (Acacia caven) & 2 & Cabernet & 1 & Manure supply & 29 \\
\hline Peach tree (Prunus persica) & 1 & & & Mineral fertilization & 2 \\
\hline \multirow[t]{2}{*}{ Nogal (Juglans australis) } & 1 & & & Tillage & 7 \\
\hline & & & & Pesticide application & 27 \\
\hline
\end{tabular}




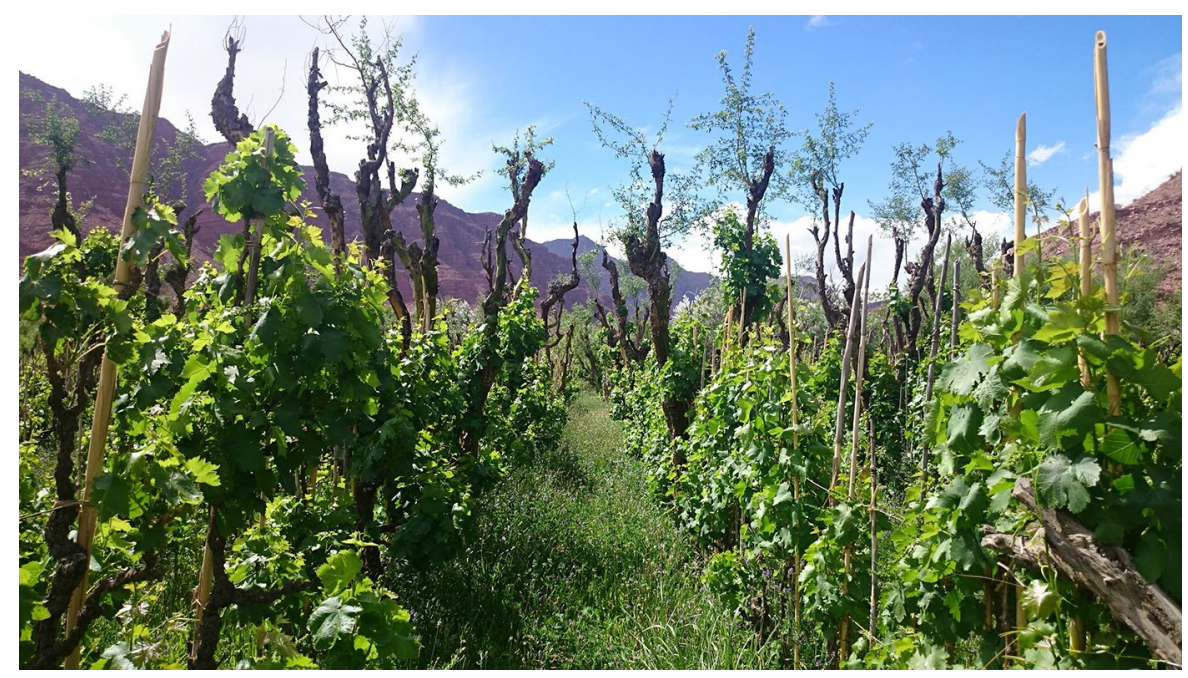

Fig. 3 An example of a vineyard with grapes grown on trees in the Cinti Valley (credit: Pablo Oliva Oller)

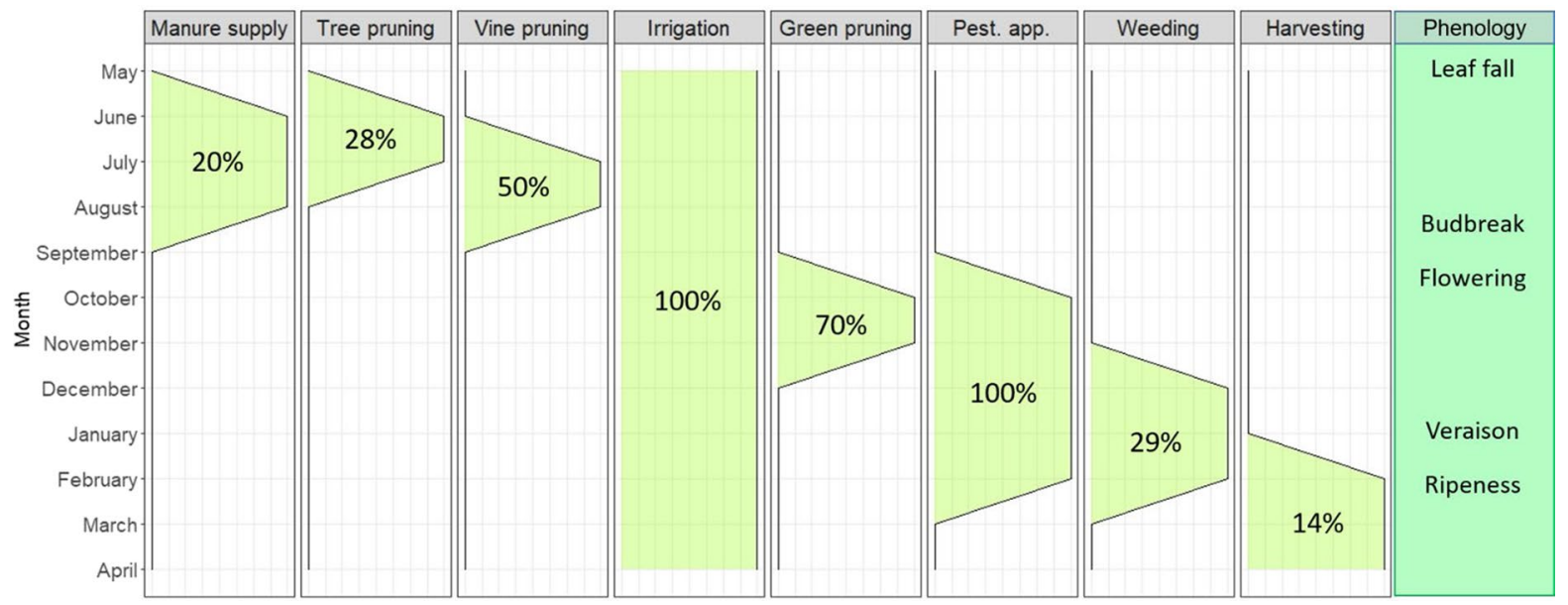

Fig. 4 The different management practices in the agroforestry vineyards throughout the year (on the left) according to the grape phenological stages (on the right). The percentages indicate the average proportion of permanent manpower that performs each practice

Tree and grapevine management in agroforestry vineyards

The management of agroforestry vineyards was carried out from May to April, with a distribution of different practices throughout the year (Fig. 4). Most practices concentrated on a particular phase of the grapevine cycle, except irrigation which had to be managed throughout, and pesticide applications, which were spread out from flowering to maturity. The permanent labor force carried out tasks such as irrigation, and pest and disease control. This permanent force included $85 \%$ family members (data not shown). Casual labor carried out between $71 \%$ and $86 \%$ of manure applications, tree pruning, weeding, and harvest.

All the grape growers applied gravity irrigation to their vineyard, with water coming from the rivers flowing in the valleys (Table 2). Most pruned their trees in June. According to the growers, this technique had several purposes: to prevent the canopy of the trees from shading the vine plants, to control the height of the trees, and to facilitate the management of grapevines (grape pruning, harvesting). They pruned grapevines in July and August, after the pruning of the trees.

Most of the grape growers applied manure during the winter months to fertilize their vineyard. The 
frequency of application was every other year and the quantity varied from 2000 to $20,000 \mathrm{~kg} \mathrm{ha}^{-1}$. Most did not use chemical fertilizers; the few that did used compound fertilizers and applied it at budbreak, with a dose ranging from 50 to $100 \mathrm{~g}$ per plant. Most grape growers did not till the soil and kept the plots grassed; some grew vegetables and alfalfa (Medicago sativa) between the trees and vines to obtain food for their own consumption or fodder for their animals.

The pests and diseases that most affected the agroforestry vineyards were powdery mildew (Erysiphe necator) ( $80 \%$ of the vineyards), spider mite (Eotetranychus carpini) (53\%), and, to a lesser extent, downy mildew (Plasmopara viticola) (23\%) and botrytis (Botrytis cinerea) (20\%). Most producers used pesticides to control pests and diseases. The number of treatments varied from one to five, depending on the year and the producer. The most-used products for powdery mildew control were sulfur-based and other fungicides of the triazole family. For the control of spider mites, insecticides based on abamectin were used. Most of the grape growers reported having suffered a severe pest or disease attack in their vineyard during its production history.

Typology of management of agroforestry vineyards

The variables "Treatment frequency" and "Cultivar diversity" positively correlated and explained most of the second dimension of the PCA (Dim2 in Fig. 5).

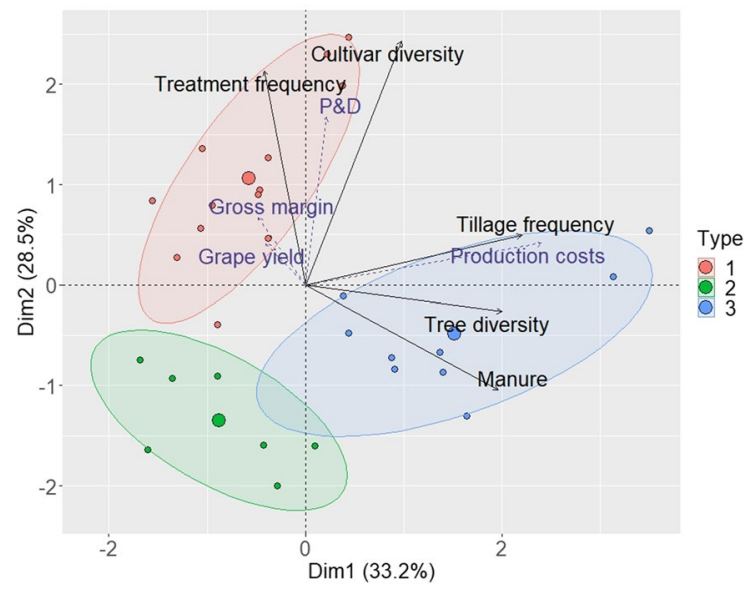

Fig. 5 Typology of vineyard management with PCA and HCA. The farming practices variables (in black) were those used to carry out the PCA and HCA. The other variables (dark blue) were performance variables (Yield, Income, Pest and Disease (P\&D), and Costs) that could be related to the management variables
On the other hand, the variables "Manure," "Tillage frequency," and "Tree diversity" positively correlated and explained most of the first dimension of the PCA (Dim1). The additional performance variables "Grape yield" and "Gross margin" were not well represented in the PCA graph. Instead, the "Production costs" variable positively correlated to "Tillage frequency" and, to a lesser extent, to the "Manure" variables. "Pests and Diseases" (P\&D) positively correlated with "Treatment frequency." The HCA analysis revealed three different types of management (Table 3, Fig. 5):

- Type 1 systems were characterized by rather low diversity of tree species and high diversity of grape cultivars; low manure application; high pesticide application; a higher number of pest and disease attacks; and average grape yield and gross margin. They belonged to producers mostly established in the Cinti Valley, with a fairly large cultivated area, and were more connected to the market and to support institutions (data not shown).

- Type 2 systems were characterized by a lower diversity of tree species; the cultivation of a single vine cultivar (mainly Vicchoqueña); lower pest and disease attacks and number of pesticide applications; and fairly high grape yield and gross margin. They belonged to producers mainly located in the Cotagaita Valley, and were less connected to the market and to support institutions.

- Type 3 systems were characterized by a high diversity of tree and vine varieties; a high amount of manure applied; low pest attacks and number of pesticide applications; and low yield and gross margin. They were mainly located in the Paicho Valley, in farms with a small vineyard area and a larger number of fruit trees in the vineyards to maximize crop production per area; these systems were less connected to support institutions and commercialized wine or brandy in the surrounding area.

\section{Services expected from trees by winegrowers}

According to the grape growers, the advantages of the tree-vine association are manifold (Table 2). The main one is that the crown of the tree protects the vines against hail, according to $37 \%$ of the growers, and $20 \%$ say that it also protects vines 
Table 3 Comparison among the three types of agroforestry vineyards of (1) the management variables, (2) the performances, and (3) the services expected by grape growers from the vine-tree association. Student's $t$-tests were performed to compare averages (1) and (2)

\begin{tabular}{|c|c|c|c|c|c|}
\hline Category & Variable & Unit & Type $1(n=13)$ & Type $2(n=7)$ & Type $3(n=9)$ \\
\hline \multirow[t]{5}{*}{ AFS management } & Tillage frequency & Tillage year ${ }^{-1}$ & $0.15 \pm 0.38$ & $0.00 \pm 0.00$ & $0.78 \pm 0.83$ \\
\hline & Tree diversity & Species plot ${ }^{-1}$ & $1.6 \pm 0.7 b$ & $1.6 \pm 0.8 b$ & $2.7 \pm 0.5 \mathrm{a}$ \\
\hline & Cultivar diversity & Varieties plot ${ }^{-1}$ & $2.5 \pm 0.5 \mathrm{a}$ & $1.0 \pm 0.0 \mathrm{~b}$ & $2.1 \pm 0.3 \mathrm{a}$ \\
\hline & Manure & $\mathrm{t} \mathrm{ha}^{-1}$ & $4.6 \pm 3.1 b$ & $8.3 \pm 5.7 \mathrm{ab}$ & $13.6 \pm 7.7 \mathrm{a}$ \\
\hline & Treatment frequency & Number year ${ }^{-1}$ & $3.8 \pm 1.1 \mathrm{a}$ & $2.3 \pm 1.2 b$ & $2.0 \pm 1.4 \mathrm{~b}$ \\
\hline \multirow[t]{4}{*}{ Agroeconomic performance assessed } & Pest and disease & Number plot ${ }^{-1}$ & $2.2 \pm 0.4 \mathrm{a}$ & $1.1 \pm 0.7 \mathrm{~b}$ & $1.8 \pm 0.8 \mathrm{ab}$ \\
\hline & Grape yield & $\mathrm{hL} \mathrm{ha}^{-1}$ & $55.5 \pm 43.9$ & $63.8 \pm 51.2$ & $31.2 \pm 16.4$ \\
\hline & Production costs & $\mathrm{USD} \mathrm{ha}^{-1}$ & $926 \pm 719$ & $536 \pm 339$ & $584 \pm 514$ \\
\hline & Gross margin & $\mathrm{USD} \mathrm{ha}^{-1}$ & $2642 \pm 2736 a$ & $3820 \pm 2926 a$ & $985 \pm 701 b$ \\
\hline \multirow[t]{8}{*}{ Services expected by farmers } & Hail protection & $\%$ & 46 & 43 & 33 \\
\hline & Protection against frost & $\%$ & 15 & 14 & 22 \\
\hline & Higher yields & $\%$ & $31 *$ & $14 *$ & $33 *$ \\
\hline & Disease control & $\%$ & $38 *$ & $14 *$ & $22 *$ \\
\hline & Vine quality & $\%$ & $8 *$ & $43 *$ & $11 *$ \\
\hline & Protection against erosion & $\%$ & 23 & 14 & 11 \\
\hline & Soil fertility & $\%$ & $15^{*}$ & $43^{*}$ & $0 *$ \\
\hline & Lower labor cost & $\%$ & $8 *$ & $29 *$ & $0 *$ \\
\hline
\end{tabular}

The presence of letters $\mathrm{a}$ and $\mathrm{b}$ shows that there were significant differences between types. The standard deviation is indicated after the \pm sign. To compare the expected services (3), the Chi-square test was used. * indicates that there was a significant difference between types

against frost. The other expected benefits are an increase in grape yield (27\%), better pest and disease control (23\%), and an improved quality of the wine $(13 \%)$. Trees also protect fields against flood damage such as soil erosion (17\%), and improve soil fertility (10\%). In addition, for $10 \%$ of the producers, the use of trees to stake the vines is a process that is quicker and less costly than conventional trellising.

Significant differences were observed between the three types of management in terms of the services expected from the tree-vine association (Table 3). Types 1 and 3 expected higher yields more frequently than type 2 , yet only type 1 achieved this aim. Type 1 had high expectations in terms of pest and disease control, whereas type 2 valued more the benefits of soil fertility and the quality of the wine. Finally, type 2 asserted more than the other two types that the association between grapevines and trees allows for a reduction in cost by significantly reducing working time and associated outlays. Of the three types, type 2 spent the least, on average, on the management of its agroforestry vineyards. We did not observe any significant difference among types in terms of expected protection against hail, frost, and flood, nor in terms of increasing the lifespan of the vineyard.

\section{Discussion}

The present research has allowed the first characterization of traditional agroforestry vineyards in southern Bolivia. Although their structure, management, and performance present specific features, they are of interest for both viticulture and agroforestry. To explore their diversity, we preferred to describe a relatively large number of vineyards by survey, rather than a necessarily smaller number by field measurements. As in Notaro et al. (2020), most agronomic and economic variables were provided by farmers, whereas the structure of the agroforestry systems was observed in the field. The wine growers asserted that 
the reason for staking vines on trees was that it provided increased benefits. This declarative approach values their experience, gives an insight into the rationale of their vineyard management, and provides hypotheses for future assessment of the services provided by companion trees (Cerdán et al. 2012). The surveyed traditional grape growing systems of southern Bolivia have a socioeconomic structure similar to other Bolivian wine growing systems, with the farms and vineyards having a small surface area and a significant part of the cultivation carried out by the family workforce (Buitrago Soliz 2014; Oliva 2021). In most cases, the vineyards occupy roughly half of the surface of the farms. The other half is devoted to other crops: vegetables, fruits, and forage. It is interesting to note that smallholders from the neighboring region of Tarija who switched to a monoculture of trellised vines still maintain the same diversity of crops within their farms (Turner and Davidson-Hunt, 2016). Although traditional systems in the high valleys use less inputs and have lower production costs than modern viticultural systems, the systems that use trees achieve lower grape yields, lower turnover and gross margin, and their economic sustainability is in question (Oliva 2021).

The density of trees in traditional vineyards is of the same order of magnitude as the one adopted in recently planted agroforestry systems (Gosme et al. 2019; Bourgade et al. 2020), yet in the latter, grapevines are not grown on trees and only one tree species is planted in each field. Another difference is that the spatial distribution of trees appears to be often unstructured in the traditional vineyards, whereas it is ordered in rows in modern agroforestry vineyards. This is certainly not without consequences, as Notaro et al. (2021) demonstrated. They showed that the spatial organization of trees has a marked effect on the production of the main crop species. The different tree densities and spatial distributions among the surveyed plots result from management rationales implemented over the long term. These remain to be deciphered, as Jagoret et al. (2011) did for cocoa agroforestry systems. The most commonly used tree species is the molle tree ( $S$. molle), which is native to the Andes and is characterized by its medium size and high tolerance to drought and high temperatures (Kramer 1957). The chañar tree ( $G$. decorticans) is another native species of the region, resistant to drought but with shallower roots and a shorter life span than the molle tree. Other species are less widespread: the taco tree $(P$. alba $)$ is much larger than the molle and chañar trees, which makes it more difficult for farmers to manage, and the peach tree is said by farmers to infect the vineyard with mites (Panonychus ulmi and Eotetranychus carpini). In two thirds of vineyards, several tree species were grown, certainly for different purposes as observed in other agroforestry systems in other regions of the world (Rigal et al. 2018).

Our survey found a high diversity of grapevine varieties and most of them are landraces (GutiérrezGamboa et al. 2020; Oliva et al. 2020), which testifies to the traditional character of the surveyed vineyards. The potential benefits of cultivar mixtures have been examined in annual crops and more rarely in perennial crops, in particular for the regulation of pests and diseases (Parisi et al. 2013); they remain to be evaluated for grapevines.

The main features of the management of traditional vineyards were the following: gravity irrigation to compensate for the low rainfall; fertilization mostly with manure in winter time; control of pests and diseases based on few applications of copper, sulfur, and synthetic pesticides; soil surface management based on no tillage, cover cropping, and, in some cases, intercropping of forage and vegetables. The sometimes high quantities of manure applied draws attention, yet they are comparable to those observed in the neighboring region of Tarija on more conventional vineyards with up to $16 \mathrm{t} \mathrm{ha}^{-1}$ per year (Oliva et al 2018), and to those found in the literature for annual crops (e.g., Cardinael et al., 2022). One of the most striking cultivation techniques is tree pruning, followed by vine pruning from June to August. Tree pruning aims to find a compromise between vine staking and access to light: unpruned trees shade crops, which affects their yield (Dufour et al. 2013). With another type of association between trees and vines and under more abundant rainfall, Lang et al. (2019) did not observe significant water or nitrogen stress suffered by vines in comparison with a monocrop plot. Unfortunately, this type of experimentation is still too rare. In our study case, the available data did not allow us to diagnose whether the low grape yields in some plots were related to competition for light or soil resources with trees.

According to the PCA analysis, a higher diversity of grapevine cultivars was not associated with a lower number of pests and diseases, nor to a lower number 
of plant protection treatments. This raises the issue of the impact of field biodiversity on the regulation of pests and diseases that is not always verified in agroforestry systems (Smits et al. 2012). Another question is the lack of correlation between the level of fertilization and the number of pesticide treatments on the one hand, and grape yield and income on the other. Intermediate variables on abiotic and biotic stress levels need to be made available to diagnose the determinants of the variations in grape yield (Guilpart et al. 2014).

Three types of cropping systems were identified. They were contrasted in terms of vineyard structure (diversity of tree species and grapevine varieties), cropping practices (fertilization and grapevine protection), and performance (yield, although not significantly, grapevine health, gross margin). Type 3 , which exhibited the highest tree and grapevine diversity and the highest manure supply, did not do better in terms of vine health and yield, and had the lowest gross margin on grape production. To refine this typology, it will be necessary to consider the biodiversity within and around the plots (including grass cover and hedges), and to evaluate the economic performance at the farm scale by also considering other crop or animal production and self-consumption (Notaro et al. 2020).

Grape growers identified benefits associated with trees that have been documented in the scientific literature about agroforestry, including in regions with a temperate climate (Lawson et al. 2019; Torralba et al. 2016). The major benefits expected from the trees is the protection of the vines against climatic hazards (hail, frost). Indeed, tree shade can protect crops from extreme temperatures such as heat waves and frost (Inurreta-Aguirre et al. 2018; Gosme et al. 2019). Trees can act as windbreaks, which can reduce evapotranspiration (Veste et al. 2020). They can also provide some protection to the vineyard from pests and diseases, either by creating favorable microclimatic conditions or by changing the balance between communities of pests and beneficial organisms (Altieri and Nicholls 2002; Barbar et al. 2006). In the surveyed region, this protection is only partial, as grape growers complain particularly about powdery mildew and spider mites. There may be confusion between the effects of plant biodiversity (not only trees) within and around the agroforestry plots (Smits et al. 2012). A third type of benefit is the protection of soils and the maintenance of its quality. The root systems of the trees located on the banks of the rivers hold the soil and limit erosion during floods. The evergreen foliage of the molle tree constantly drops leaf litter to the ground, and this mulch prevents evaporation (Stadler-Kaulich 2014). The deposit of this litter and the turnover of the root systems of trees and grass cover increases the organic matter content of the soil, its fertility, and biological activity (d'Hervilly et al. 2021). Lastly, some producers claim a positive impact of trees on grape yield and quality. This could be explained by the provision of the support and regulation services described above, yet we did not collect evidence of this in the field. It would be interesting to check if the global productivity increases (land equivalent ratio $>1$ ) when trees and other crops are grown in association with vines (Torralba et al. 2016).This information would indicate whether there is competition or facilitation among species (Malézieux et al. 2009).

\section{Conclusion}

The present study describes the main features and performances of a type of viticulture, in the form of agroforestry, that was common in the past, but which has virtually disappeared today. It reveals that, in the conditions of southern Bolivia, agroforestry viticulture provides a high potential for promoting the provision of ecosystem services. This result is in line with the benefits of promoting higher biodiversity based on herbaceous (Garcia et al. 2018) or tree species (Gosme et al. 2019) that have been highlighted in other vineyards of the world. The relationships between species composition and the spatial organization of the agroforestry vineyards, their management, and the ecosystem services actually produced, must still be assessed from in-field measurements in a wide range of conditions. The link between environmental sustainability at the field scale and economic and social sustainability at the farm scale also remains to be investigated.

Acknowledgements We would like to thank IDEPRO Desarrollo Empresarial, the FAUTAPO Foundation and the traditional winegrowers of the Southern Valleys of Bolivia, without whom this work would not have been possible.

Authors' contributions The preparation and execution of the surveys were carried out by P.O.O. The data analyses were performed by P.O.O. and M.N. All authors contributed to the writing of the manuscript and approved its final version. 
Funding No specific funding was received for conducting this study.

Availability of data and materials The collection and storage of the data complied with the requirements of personal data protection.

Code availability Not applicable.

\section{Declarations}

Conflict of interest Not applicable.

Ethics approval Not applicable.

Consent to participate Not applicable.

Consent for publication Not applicable.

Humans and animals rights Not applicable.

Open Access This article is licensed under a Creative Commons Attribution 4.0 International License, which permits use, sharing, adaptation, distribution and reproduction in any medium or format, as long as you give appropriate credit to the original author(s) and the source, provide a link to the Creative Commons licence, and indicate if changes were made. The images or other third party material in this article are included in the article's Creative Commons licence, unless indicated otherwise in a credit line to the material. If material is not included in the article's Creative Commons licence and your intended use is not permitted by statutory regulation or exceeds the permitted use, you will need to obtain permission directly from the copyright holder. To view a copy of this licence, visit http://creativecommons.org/licenses/by/4.0/.

\section{References}

Altieri MA, Nicholls CI (2002) The simplification of traditional vineyard-based agroforests in northwestern Portugal: some ecological implications. Agrofor Syst 56:185191. https://doi.org/10.1023/A:1021366910336

Barbar Z, Tixier MS, Cheval B, Kreiter S (2006) Effects of agroforestry on phytoseiid mite communities (Acari: Phytoseiidae) in vineyards in the South of France. Exp Appl Acarol 40(3-4):175-188. https://doi.org/10.1007/ s10493-006-9044-z

Bourgade E, Alonso Ugaglia A, Bustillo V, Dufourcq T, Grimaldi J, Guenser J, Montagne V, Ranjard L (2020) VITIFOREST: Evaluation de l'impact de l'arbre agroforestier en contexte viticole. Innov Agron 79:471-497

Buitrago Soliz A (2014) La vitivinicultura emergente en Bolivia y las oportunidades para el Singani. RIVAR 1:90-102

Cardinael R, Guibert H, Kouassi Brédoumy ST, Gigou J, N'Goran KE, Corbeels M (2022) Sustaining maize yields and soil carbon following land clearing in the forestsavannah transition zone of West Africa: results from a 20-year experiment. Field Crops Res 275:108335. https:// doi.org/10.1016/j.fcr.2021.108335

Cerdán CR, Rebolledo MC, Soto G, Rapidel B, Sinclair FL (2012) Local knowledge of impacts of tree cover on ecosystem services in smallholder coffee production systems. Agric Syst 110:119-130. https://doi.org/10.1016/j.agsy. 2012.03.014

Chuya N (2011) Validación de cuatro variedades de vid en la cuenca del río Cotagaita y Tumusla, Foniciv, Cotagaita (Bolivia). https://drive.google.com/file/d/1oKEg6zKld3PoZlgP28zdKypHMHu_wld/view

Conway G (1987) The properties of agroecosystems. Agric Syst 24(2):95-117

D’Hervilly C, Marsden C, Capowiez Y, Béral C, Delapré-Cosset L, Bertrand I (2021) Trees and herbaceous vegetation strips both contribute to changes in soil fertility and soil organism communities in an agroforestry system. Plant Soil. https://doi.org/10.1007/s11104-021-04932-x

Dufour L, Metay A, Talbot G, Dupraz C (2013) Assessing light competition for cereal production in temperate agroforestry systems using experimentation and crop modelling. J Agron Crop Sci 199:217-227. https://doi.org/10.1111/ jac. 12008

Dupraz C, Liagre F (2019) Agroforesterie: des arbres et des cultures. France Agricole Editions, Paris, p 432

Duru M, Therond O, Martin G, Martin-Clouaire R, Magne MA, Justes E, Journet EP, Aubertot JN, Savary S, Bergez JE, Sarthou JP (2015) How to implement biodiversitybased agriculture to enhance ecosystem services: a review. Agron Sustain Dev 35:1259-1281. https://doi.org/10. 1016/j.jenvman.2010.11.019

Escobar G, Berdegué J (1990) Tipificación de sistemas de producción agrícola. Red Internacional de Metodología de Investigación de Sistemas de Producción (RIMISP), Santiago de Chile

FAUTAPO (2010) Catastro vitícola de los valles del sur de Bolivia, Programa de fortalecimiento al complejo uvas vinos y singanis. Tarija

Garcia L, Celette F, Gary C, Ripoche A, Valdés-Gómez H, Metay A (2018) Management of service crops for the provision of ecosystem services in vineyards: a review. Agric Ecosyst Environ 251:158-170. https://doi.org/10.1016/j. agee.2017.09.030

Gosme M, Grimaldi J, Trambouze W (2019) Diachronic study of the effect of growing trees on grapevine yield: 24 years of experience in the South of France. In: Dupraz C, Gosme M, Lawson G (eds) 4th world congress on agroforestry, 2019-05-20/2019-05-22, Montpellier (France). Book of abstracts. Montpellier: CIRAD, INRA, p 58. https://hal.inrae.fr/hal-02736832/document. Accessed Dec 2021

Guilpart N, Metay A, Gary C (2014) Grapevine bud fertility and number of berries per bunch are determined by water and nitrogen stress around flowering in the previous year. Eur J Agron 54:9-20. https://doi.org/10.1016/j.eja.2013. 11.002

Gutiérrez-Gamboa G, Liu SY, Pszczólkowski P (2020) Resurgence of minority and autochthonous grapevine varieties in South America: a review of their oenological potential. J Sci Food Agric 100:465-482. https://doi.org/10.1002/ jsfa. 10003 
Inurreta-Aguirre HD, Lauri PÉ, Dupraz C, Gosme M (2018) Yield components and phenology of durum wheat in a Mediterranean alley-cropping system. Agrofor Syst 92:961-974. https://doi.org/10.1007/s10457-018-0201-2

Jagoret P, Michel-Dounias I, Malézieux E (2011) Long-term dynamics of cocoa agroforests: a case study in central Cameroon. Agrofor Syst 81:267-278. https://doi.org/10. 1007/s10457-010-9368-x

Keller M (2020) The science of grapevines. Academic Press, London

Kramer FL (1957) The pepper tree, Schinus molle L. Econ Bot 11:322-326. https://doi.org/10.1007/BF02903811

Lang CP, Merkt N, Geilfus CM, Graeff-Hönninger S, Simon J, Rennenberg H, Zörb C (2019) Interaction between grapevines and trees: effects on water relations, nitrogen nutrition, and wine. Arch Agron Soil Sci 65:224-239. https:// doi.org/10.1080/03650340.2018.1493197

Lawson G, Dupraz C, Watté J (2019) Can silvoarable systems maintain yield, resilience, and diversity in the face of changing environments? In: Lemaire G, De Faccio Carvalho PC, Kronberg S, Recous S (eds) Agroecosystem diversity. Academic Press, London, pp 145-168. https:// doi.org/10.1016/B978-0-12-811050-8.00009-1

Lê S, Josse J, Husson F (2008) FactoMineR: an R package for multivariate analysis. J Stat Softw 25:1-18

Malézieux E, Crozat Y, Dupraz C, Laurans M, Makowski D, Ozier-Lafontaine H, Rapidel B, de Tourdonnet S, Valantin-Morison M (2009) Mixing plant species in cropping systems: concepts, tools and models: a review. In: Lichtfouse E, Navarrete M, Debaeke P, Véronique S, Alberola C (eds) Sustainable agriculture. Springer, Dordrecht, pp 329-353. https://doi.org/10.1007/978-90-481-2666-8_22

Maraux F, Malezieux E, Gary C (2013) From artificialization to the ecologization of cropping systems. In: Hainzelin E (ed) Cultivating biodiversity to transform agriculture. Springer, Dordrecht, pp 45-90. https://doi.org/10.1007/ 978-94-007-7984-6_3

Municipio Méndez (2009) Diagnóstico Municipal Consolidado, Honorable Alcaldía Municipal de la Provincia Méndez. Tarija

Molina Antelo JC, Caba Olguín MJ, Flores Montes NG, Mendoza Sánchez O, Villena W (2011) Zonificación de áreas con potencial vitícola en el cañón de los Cintis. Fundación Fautapo, Murillo

Notaro M, Gary C, Deheuvels O (2020) Plant diversity and density in cocoa-based agroforestry systems: how farmers' income is affected in the Dominican Republic. Agrofor Syst 94:1071-1084. https://doi.org/10.1007/ s10457-019-00472-7

Notaro M, Collado C, Depas JK, Dumovil D, Denis AJ, Deheuvels O, Tixier P, Gary C (2021) The spatial distribution and height of associated crops influence cocoa tree productivity in complex agroforestry systems. Agron Sustain Dev 41:60. https://doi.org/10.1007/s13593-021-00716-w

Oliva P (2021) Caracterización de los productores de vid de las principales zonas vitivinícolas de Bolivia. RIVAR 8:5170. https://doi.org/10.35588/rivar.v8i23.4945

Oliva P, Flores Higueras E, Espinoza Marquez L (2018) Diagnóstico de fertilidad de suelos y técnicas de fertilización en viñedos comerciales del valle central de Tarija. Agrociencias 3:7-17
Oliva P, Langer E, Gary C, Aillon E (2019) Un ejemplo de agroforestería vitícola: los sistemas de uvas tradicionales del Valle de los Cintis, Bolivia. XVI Congreso Latinoamericano de Viticultura y Enología, 26-30 Nov 2019, Ica (Peru), pp 142-146. https://hal.inrae.fr/hal-02734990

Oliva P, Mejia N, Ocarez N (2020) Génética de uvas patrimoniales y criollas en el valle de los Cintis. Idepro IFD Bolivia. https://www.idepro.org/files/uploads/SeparataZI DEPROZVITIVINICOLA_10.pdf

Paris P, Camilli F, Rosati A, Mantino A, Mezzalira G, Dalla Valle C, Franca A, Seddaiu G, Pisanelli A, Lauteri M, Brunori A, Re GA, Sanna F, Ragaglini G, Mele M, Ferrario V, Burgess PJ (2019) What is the future for agroforestry in Italy? Agrofor Syst 93:2243-2256. https://doi.org/ 10.1007/s10457-019-00346-y

Parisi L, Gros C, Combe F, Parveaud CE, Gomez C, Brun L (2013) Impact of a cultivar mixture on scab, powdery mildew and rosy aphid in an organic apple orchard. Crop Prot 43:207-212

R Core Team (2020) R: a language and environment for statistical computing. R Foundation for Statistical Computing, Vienna

Rigal C, Vaast P, Xu J (2018) Using farmers' local knowledge of tree provision of ecosystem services to strengthen the emergence of coffee-agroforestry landscapes in southwest China. PLoS ONE 13:e0204046. https://doi.org/10.1371/ journal.pone.0204046

SENAMHI (2020) Informe Meteorológico, estación Paicho Centro. Tarija, Bolivia. http://senamhi.gob.bo/sismet

Smits N, Dupraz C, Dufour L (2012) Unexpected lack of influence of tree rows on the dynamics of wheat aphids and their natural enemies in a temperate agroforestry system. Agrofor Syst 85:153-164. https://doi.org/10.1007/ s10457-011-9473-5

Stadler-Kaulich N (2014) La Agroforestería - el vivir bien en la diversidad. Acta Nova 6:288-293

Torralba M, Fagerholm N, Burgess PJ, Moreno G, Plieninger T (2016) Do European agroforestry systems enhance biodiversity and ecosystem services? A meta-analysis. Agric Ecosyst Environ 230:150-161. https://doi.org/10.1016/j. agee.2016.06.002

Turner KL, Davidson-Hunt IJ (2016) Tensions and synergies in the Central Valley of Tarija, Bolivia: commercial viticulture and agrobiodiversity in smallholder farming systems. Agroecol Sustain Food Syst 40:518-552. https://doi.org/ $10.1080 / 21683565.2016 .1151473$

Van Limbergen D (2020) Agroforestry and the reappraisal of Roman viticulture. Glob Environ 13:432-450. https://doi. org/10.3197/ge.2020.130208

Veste M, Littmann T, Kunneke A, Du Toit B, Seifert T (2020) Windbreaks as part of climate-smart landscapes reduce evapotranspiration in vineyards, Western Cape Province, South Africa. Plant Soil Environ 66:119-127. https://doi. org/10.17221/616/2019-PSE

Publisher's Note Springer Nature remains neutral with regard to jurisdictional claims in published maps and institutional affiliations. 